\title{
BioLink
}

JURNAL BIOLOGI LINGKUNGAN, INDUSTRI, KESEHATAN

Available online http://ojs.uma.ac.id/index.php/biolink

\section{KAJIAN PEMANFAATAN TUMBUHAN OBAT PADA MASYARAKAT SUKU SIMALUNGUN DI KECAMATAN RAYA DESA RAYA BAYU DAN RAYA HULUAN KABUPATEN SIMALUNGUN}

\section{STUDY THE UTILIZATION OF MEDICINAL PLANTS IN ETHNIC COMMUNITIES SIMALUNGUN IN RAYA VILLAGE RAYA BAYU AND RAYA HULUAN DISTRICT SIMALUNGUN}

\author{
Toberni S. Situmorang1), Eka Saudur R. Sihombing2) \\ 1)Program Studi Analis Kesehatan Fakultas Kesehatan Universitas Efarina \\ 2) Program Studi Kesehatan Masyarakat Fakultas Kesehatan Universitas Efarina
}

*Corresponding author: E-mail : toberni santika@yahoo.com

\section{Abstrak}

Penelitian ini bertujuan untuk mengetahui jenis-jenis tumbuhan yang dimanfaatkan sebagai obat tradisional, cara meramu, cara pengobatan, dan khasiatnya pada masyarakat suku Simalungun di Desa Raya Bayu dan Raya Huluan. Metode yang dilakukan dalam pengambilan data adalah survei eksploratif dan metode Participatory Rural Appraisal, yaitu proses pengkajian yang berorientasi pada keterlibatan dan peran masyarakat secara aktif dalam penelitian. Variabel yang diamati meliputi jenis tumbuhan, pemanfaatan bagian tumbuhan, cara meramu, bagian yang digunakan, dan khasiatnya. Hasil penelitian menunjukkan bahwa Diperoleh 53 Jenis Tumbuhan Obat yang terdiri dari 25 Ordo dan 33 Famili dari informasi 2 battra, Diperoleh 43 jenis ramuan dari 34 jenis penyakit, Famili Zingiberaceae merupakan famili yang paling banyak digunakan sebagai obat tradisional yaitu 12,96\%, Bagian organ tumbuhan yang digunakan sebagai bahan obat tradisional adalah bagian daun dengan persentase $52,08 \%$, Sumber Tumbuhan obat paling adalah hasil budidaya dengan nilai 75,46\%, Ramuan Obat yang paling banyak digunakan adalah Ramuan Obat lambung, Hipertensi, Diabetes, Asam Urat dan Lever.

Kata kunci: Tumbuhan Obat, Obat tradisional, Simalungun

\begin{abstract}
This reseach aims to determine the types of plants that are used as traditional medicine, how to mix, the way of treatment, and khasiatnya to the tribal community Simalungun in Raya Raya Bayu and Raya Huluan. Methods taken in data collection are explorative surveys and Participatory Rural Appraisal methods, which are process-oriented studies of community involvement and active role in research. Observed variables include plant species, utilization of plant parts, how to mix, the parts used, and usefulness. The results showed that 53 types of medicinal plants consisting of 25 Orders and 33 families of information 2 battra, obtained 43 types of herbs from 34 types of diseases, Family Zingiberaceae is the family most widely used as a traditional medicine that is $12.96 \%$, part organ herbs used as traditional medicinal ingredients are the leaves with a percentage of 52.08\%, most medicinal plants are cultivated with a value of $75.46 \%$, the most widely used Medicinal Herbs are Herbs, Hypertension, Diabetes, Uric Acid and Lever.
\end{abstract}

Keywords: Medicinal plants, traditional medicine, Simalungun

How to Cite: Situmorang, T.S. dan Sihombing, E.S.R, 2018, Kajian Pemanfaatan Tumbuhan Obat Pada Masyarakat Suku Simalungun Di Kecamatan Raya Desa Raya Bayu dan Raya Huluan Kabupaten Simalungun, BioLink, Vol. 4 (2): Hal. 112-120 


\section{PENDAHULUAN}

Pengobatan tradisional merupakan bagian dari sistem budaya masyarakat yang potensi manfaatnya sangat besar dalam pembangunan kesehatan masyarakat. Pemanfaatan obat tradisional untuk pengobatan sendiri (self care) cenderung meningkat. Pada tahun 1999 baru mencapai 20,5 persen, sementara itu menurut hasil Survei Sosial Ekonomi Nasional (Susenas) di tahun 2001 angkanya menjadi 31,7 persen dan 9,8\% memilih cara pengobatan tradisional lainnya. Secara internasional obat-obat tradisional yang menggunakan bahan-bahan dari tumbuhan (herbal medicine) lebih maju.

Etnobotani merupakan ilmu botani yang mepelajari tentang pemanfaatan tumbuh-tumbuhan dalam keperluan hidup sehari-hari dan adat suku bangsa (Martin, 2004). Pengetahuan tradisional yang dimiliki setiap suku atau etnis tersebut, diwariskan secara turun temurun, contohnya yaitu penggunaan tumbuhan sebagai obat untuk menyembuhkan penyakit (Bodeker, 2000)

Kecamatan Raya merupakan salah satu daerah yang masih menjaga tradisi leluhur dalam memanfaatkan tanaman sebagai obat untuk mengobati suatu penyakit maupun mencegah penyakit. Desa-desa di kecamatan ini masih memiliki kekayaan pengetahuan tradisional dalam bidang pengobatan tradisional atau jamu khususnya yang berkaitan untuk menyembuhkan penyakit. Selain itu desa-desa ini memiliki keanekaragaman tumbuhan yang cukup tinggi.

Kecamatan Raya dipilih menjadi satu diantara beberapa daerah untuk pengembangan dan pemanfaatan tumbuhan obat didasarkan kepada pertimbangan, yaitu : (1) potensi tumbuhan obat untuk jamu masih beranekaragam, (2) desa ini dikenal dengan masyarakatnya yang masih mempunyai kekayaan pengetahuan tentang pemanfaatan tumbuhan untuk obat, (3) tersedianya lahan yang sesuai secara ekologis untuk pengembangan budidaya tumbuhan obat.

\section{METODE PENELITIAN}

Penelitian ini dilaksanakan untuketnis Simalungun di Kabupaten Simalungun, Kecamatan Raya, Desa Raya Bayu dan Raya Huluan, Provinsi Sumatera Utara.

Populasi pada penelitian ini adalah masyarakat Desa Raya Bayu dan Raya Huluan. Desa pada kecamatan Raya tersebut memiliki potensi tumbuhan obat dengan indikasi bayak didapati pembudidayaan tumbuhan obat dan terdapat penjual tumbuhan obat serta simplisianya. Sampel dalam penelitian terdiri dari informan kunci (key informant) dan non informan kunci dari 2 desa yaitu Desa Raya Bayu dan Raya Huluan. Teknik pengambilan sampel dalam penelitian ini dengan cara purposive sampling yaitu pemilihan sampel dengan pertimbangan yakni sampel adalah seseorang yang memahami tentang tumbuhan obat. Sampel dibagi menjadi 2 golongan, yakni

1. Informan kunci meliputi :

a. Tabib/dukun (orang yang memahami jenis tumbuhan obat, cara pemanfaatannya dan relative banyak dikunjungi oleh masyarakat untuk berobat). 
Situmorang, T.S. dan Sihombing, E.S.R, Kajian Pemanfaatan Tumbuhan Obat Pada Masyarakat

b. Sesepuh kampong (orang yang memahami jenis tumbuhan obat, cara pemanfaatannya tetapi relative tidak dikunjungi oleh mesyarakat untuk berobat)

2. Informan non Kunci (orang yang memahami tentang tumbuhan obat dari informan kunci sekaligus mengkonsumsinya)

Metode yang dilakukan dalam pengambilan data adalah survei eksploratif dan metode Participatory Rural Appraisal, yaitu proses pengkajian yang berorientasi pada keterlibatan dan peran masyarakat secara aktif dalam penelitian (Martin, 1995). Keterlibatan masyarakat diperoleh melalui wawancara dengan teknik wawancara semi struktural yang berpedoman pada daftar pertanyaan seperti: nama lokal tanaman, bagian yang dimanfaatkan, manfaatnya, cara pemanfaatannya, status tanaman (liar/budidaya) dan lainnya (Supriati \& Kasrina, 2003). Setiap tumbuhan yang digunakan sebagai bahan obat tradisional difoto dan diambil contohnya untuk dikoleksi yang selanjutnya dibuat herbarium untuk dilakukan determinasi. Jika ditemukan jenis tumbuhan yang tidak dapat di identifikasi. Data yang diperoleh dianalisis secara deskriptif yang dilakukan dalam dua bentuk pendekatan yaitu pendekatan antropologi medikal dan pendekatan etnobotani medikal.

Analisis data dalam penelitian ini menggunakan teknis analisis deskriptif kualitatif dan kuantitatif. Analisis ini merupakan analisis isi (content analysis) berdasarkan data pengetahuan responden terhadap tumbuhan sebagai obat. Data kualitatif didapat dari hasil wawancara masyarakat untuk mengetahui jenis tumbuhan, organ nyang digunakan, sumber perolehan dan cara pemanfaatan tumbuhan yang digunakan sebagai obat. Sedangkan data kuantitatif berupa persentase penggunaan tumbuhan obat berupa organ tumbuhan, sumber perolehan tumbuhan dan tingkat penggunaan jenis tumbuhan yang digunakan sebagai obat diakhiri dengan Mikrosoft Office Exel. Identifikasi tumbuhan dicocokkan dengan literature yang mendukung.

\section{HASIL DAN PEMBAHASAN}

Demografi Informan/Battra

Tabel 1. Demografi Informan/Battra

\begin{tabular}{lllll}
\hline No. & Informan & Usia & Desa & Ramuan \\
\hline 1. & Tomson & 65 & Raya & 16 \\
& Purba & & Bayu & \\
2. & $\begin{array}{l}\text { Rolina Br. } 89 \\
\text { Sipayung }\end{array}$ & $\begin{array}{l}\text { Raya } \\
\text { Huluan }\end{array}$ \\
\hline \multicolumn{4}{c}{ Jumlah } \\
\hline
\end{tabular}

Dari Tabel 1. Dapat dilihat bahwa Informan yang telah diwawancari terdiri dari 2 Battra dimana masing-masing battra mewakili setiap Desa di Kecamatan Raya, Kabupaten Simalungun, yang terdiri dari Desa Raya Bayu, dan Raya Huluan. Battra No.2 yaitu Ibu Rolina Br. Sipayung memiliki jumlah ramuan paling banyak yaitu 27 Ramuan seperti pengobatan Sinusitis, Obat Ginjal, Malaria, Lever, Batuk, Obat lambung, Pegal Linu, Penetral Racun, Diare, Kurap, Panas Dalam, Hipertensi, Ambeien, Diabetes, Asam Urat, Kencing Darah, Bisulan, Disentri, Janutung Koroner, Kanker Rahim, Batu Ginjal, Kolesterol, Kesuburan, TBC, Pelancar Haid, Kencing nanah, dan Masuk angin . Hal ini disebabkan karena Batrra Ibu Rolina Br. Sipayung lebih lama menjadi 
pengobat dibandingkan battra Tomson

Purba. Gejala/Penyakit yang Ditangani Informan/Battra

Tabel 2. Gejala/Penyakit Terbanyak yang ditangani oleh informan/Battra Suku Simalungun

\begin{tabular}{llc} 
No. & Penyakit/Gejala & $\begin{array}{c}\text { Jumlah } \\
\text { Ramuan }\end{array}$ \\
\hline 1. & Lambung & 5 \\
2. & Hipertensi & 4 \\
3. & Lever & 3 \\
4. & Asam Urat & 3 \\
5. & Diabetes & 3 \\
6. & Penetral & 2 \\
& Racun/Keracunan & \\
7. & Diare & 2 \\
8. & Ambeien & 2 \\
9. & Pelancar Haid & 2 \\
10. & Batu Ginjal & 2
\end{tabular}

11. Malaria 2

12. Batuk 2

Dari Tabel 2. Dapat dilihat bahwa

12 dari 34 jenis gejala/penyakit yang lebih banyak ditangani oleh informan/Battra. Jenis gejala/penyakit yang mendominasi yang berkaitan dengan perilaku hidup dalam pola makan seperti penyakit lambung dan hipertensi.

Tabel 3. Tumbuhan-tumbuhan yang dimanfaatkan sebagai Obat Tradisonal Oleh Masyarakat Suku Simalungun di Kecamatan Raya Desa Raya bayu, dan Raya Huluan Kabupaten Simalungun

\begin{tabular}{|c|c|c|c|c|c|}
\hline Taksa & Nama Ilmiah & Nama Lokal & $\begin{array}{l}\text { Organ Yang } \\
\text { digunakan }\end{array}$ & Kegunaan & Asal T0 \\
\hline I. APIALES & 1. Anethum graveolens & Adas & Daun & Kanker rahim & Beli \\
\hline 1. Apiaceae & 2. Apium graveolens & Seledri & Batang, Daun & Hipertensi & Budidaya \\
\hline $\begin{array}{l}\text { II. ARECALES } \\
\text { 2. Arecaceae }\end{array}$ & 3. Areca catechu & Pinang & Buah & Keputihan & Beli \\
\hline $\begin{array}{l}\text { III. ASPARAGALES } \\
\text { 3. Asphodelaceae }\end{array}$ & 4. Aloe vera & Lidah buaya & Batang & $\mathrm{TBC}$ & Budidaya \\
\hline IV. ASTERALES & 5. Gynura segetum & Daun Dewa & Daun & Hipertensi & Budidaya \\
\hline 4. Asteraceae & 6. Sonchus arvensis & Tempuyung & Daun & Batu ginjal & Liar \\
\hline $\begin{array}{l}\text { V. BROMELIALES } \\
\text { 5. Bromeliaceae }\end{array}$ & 7. Ananas comosus & Nanas Hijau & Buah & Batu ginjal & Budidaya \\
\hline $\begin{array}{l}\text { VI. CAPPARALES } \\
\text { 6. Moringaceae }\end{array}$ & 8. Moringa oleifera & Kelor & Daun & Obat batuk & Budidaya \\
\hline $\begin{array}{l}\text { VII. CARYPHYLLALES } \\
\text { 7. Nyctaginaceae }\end{array}$ & 9. Bougainvillea sp. & Bunga kertas & Bunga & Pelancar Haid & Budidaya \\
\hline $\begin{array}{l}\text { VIII. EUPHORBIALES } \\
\text { 8. Euphorbiaceae }\end{array}$ & 10. Manihot esculenta & Singkong/Ubi & Daun & $\begin{array}{l}\text { Kencing darah, } \\
\text { luka bakar }\end{array}$ & Budidaya \\
\hline IX. FABALES & 11. Cassia alata & Ketepeng & Daun & Kurap & Liar \\
\hline 9. Fabaceae & 12. Tamarindus indica & Asam jawa & Buah & Lambung & Beli \\
\hline X. LAMIALES & 13. Ocimum basilicum & Kemangi & Daun & $\begin{array}{l}\text { Keputihan, } \\
\text { Kanker }\end{array}$ & Budidaya \\
\hline 10. Lamiaceae & $\begin{array}{l}\text { 14. Orthosiphon } \\
\text { stamineus }\end{array}$ & Kumis Kucing & Daun & Obat Ginjal & Budidaya \\
\hline 11. Verbenaceae & 15. Vitex trifolia & Legunde & Daun & Sinusitis & Budidaya \\
\hline XI. LAURALES & $\begin{array}{l}16 . \quad \text { Cinnamomum } \\
\text { burmannii }\end{array}$ & Kayu manis & Kulit Batang & Obat pegal Linu & Beli \\
\hline 12. Lauraceae & 17. Persea americana & Alpukat & Daun & $\begin{array}{l}\text { Obat Ginjal, } \\
\text { Diabetes }\end{array}$ & Budidaya \\
\hline $\begin{array}{l}\text { XII. LILIALES } \\
\text { 13. Amaryllidaceae }\end{array}$ & 18. Crinum jagus & Орри-орри & Daun & Obat Terkilir & Liar \\
\hline 14. Liliaceae & $\begin{array}{l}\text { 19. Allium cepa } \\
\text { 20. Allium sativum }\end{array}$ & $\begin{array}{l}\text { Bawang merah } \\
\text { Bawang Putih }\end{array}$ & $\begin{array}{l}\text { Umbi } \\
\text { Umbi }\end{array}$ & $\begin{array}{l}\text { Jantung koroner } \\
\text { Keracunan }\end{array}$ & $\begin{array}{l}\text { Budidaya } \\
\text { Budidaya }\end{array}$ \\
\hline
\end{tabular}


Situmorang, T.S. dan Sihombing, E.S.R, Kajian Pemanfaatan Tumbuhan Obat Pada Masyarakat

XIII. MAGNOLIALES

15. Annonaceae

16. Magnoliaceae

XIV. MALVALES

17. Elaecarpaceae

18. Malvaceae

XV. MYRTALES

19. Myrtaceae

20. Thymelaeaceae

XVI. PIPERALES

21. Piperaceae

XVII. PLANTAGINALES

22. Plantaginaceae

XVIII. POALES

23. Poaceae

XIX. RANUNCULALES

24. Menispermaceae

XX. RUBIALES

25. Clusiaceae

26. Rubiaceae

XXI. SAPINDALES

27. Anacardiaceae

28. Rutaceae

XXII. SCROPHULARIALES

29. Acanthaceae

XXIII. SOLANALES

30. Solanaceae

XXIV. VIOLALES

31. Caricaceae

32. Cucurbitaceae

XXV. ZINGIBERALES

33. Musaceae

34. Zingiberaceae

21. Annona muricata
22. Michelia alba
23. Muntingia calabura
24. Hibiscus mutabilis
25. Sida rhombifolia
26. Eugenia uniflora
27. Psidium guajava

28.

macrocarpa

39. Piper betle

30. Piper crocatum

31. Piper cubeba

32. Plantago major

33. Cymbopogon nardus

34. Zea mays

35. Tinospora cordifolia

36. Garcinia

mangostana

Garcinia

37. Morinda citrifolia

38. Mangifera indica

39. Citrus aurantifolia

40. Strobilanthes crispus

41. Capsicum annum

42. Physalis minima

43. Solanum melongena

44. Carica papaya

45. Cucurbita moschata

46. Musa paradisiaca

47. Alpinia galanga

48. Curcuma sp

49. Curcuma longa

50.

xanthorrhiza

51. Kaemferia galanga

52. Zingiber officinale

53. Zingiber zerumbet
Kunyit

Sirsak

Bunga kantil

Seri

Purbajolma

Sidaguri

Buah dewandaru

Jambu biji

Mahkota dewa

Daun sirih

Sirih merah

Kemukus

Daun sendok-

sendok

Serei

Jagung

Brotowali

Manggis

Mengkudu

Mangga

Jeruk nipis

Kejibeling

Cabei merah

Ciplukan

Terong Ungu

Pepaya

Labu Kuning

Jantung pisang

Lengkuas

Kunyit Putih

Temulawak

Kencur

Jahe

Lempuyang

Daun
Bunga
Daun
Daun
Daun
Buah
Daun
Buah

Daun

Daun

Biji

Daun

Batang

Biji

Batang

Kulit buah

Buah

Kulit buah

muda

Buah

Daun

Daun

Daun, Buah

Batang

Daun

Buah

Tandan

Rimpang

Rimpang

(

Rimpang

Rimpang

Rimpang

Rimpang Rimpang
Asam Urat

Obat lambung

Budidaya

Budidaya

Kesuburan Liar

Asam urat Liar

Asam lambung

Diare, Demam

berdarah

Hipertensi

Budidaya

Budidaya

Budidaya

Ambeien,

Keputihan

Budidaya

Jantung koroner, asam urat, lever

Jantung Koroner

Batu empedu

Kencing nanah

Disentri

Obat malaria

Kanker

payudara

Hipertensi,

Diabetes, Asam Budidaya

urat

Pelancar haid

Budidaya

Obat lambung

Budidaya

Obat Ginjal

Budidaya

Bisulan

Batu Ginjal

Budidaya

Liar

Kolestrol

Budidaya

Budidaya

Malaria, Lever

Budidaya

Budidaya

Budidaya

Obat Pegal Linu

Obat Lambung,

Kanker

Payudara, Masuk

angin

Penetral racun,

Panas dalam,

Obat Lambung,

Asam Urat

Lever, Asam urat Budidaya

Obat Pegal Linu Budidaya

Keputihan Budidaya Obat lambung Budidaya
Dari Tabel 3. di atas dapat dilihat bahwa Tumbuh-tumbuhan yang dimanfaatkan sebagai Obat tradisional oleh masyarakat suku Simalungun terdiri dari 25 Ordo, 34 Famili dan 53 Jenis tumbuhan dan 43 Ramuan dengan 34 Jenis Penyakit yang diperoleh dari 2 Battra. 
Menurut Auliana (2014), menjelaskan bahwa salah satu kelompok tumbuhan yang berpotensi sebagai obat adalah dari suku Zingiberaceae. Suku Zingiberaceae adalah jenis tumbuhan temu-temuan atau jahe-jahean yang memiliki rimpang dan berbau khas. Tumbuhan dari suku Zingiberaceae sangat sering dijumpai di kawasan Indonesia, hal ini dikarenakan Indonesia beriklim tropis yang sangat sesuai untuk tumbuhnya berbagai jenis tumbuhan dari suku Zingiberaceae.

Terdapat 43 jenis ramuan dalam dimanfaatkan oleh masyarakat suku Simalungun yaitu Sinusitis, Obat Ginjal, Obat Malaria, Obat Lever, Obat Batuk, Lambung, Pegal Linu, Penetralisir Racun, Diare, Kurap, Panas Dalam, Hipertensi, Ambeien, Batu Ginjal, Keputihan, Pelancar Haid, Asam Urat, Diabetes, Kencing Darah, Deman Berdasar, Terkilir, Bisulan, Malaria, Disentri, Luka Bakar, Jantung Koroner, Kanker Rahim, Kencing nanah, Batu Empedu, Kolesterol, Masuk Angin, TBC, Kanker, dan Kesuburan.

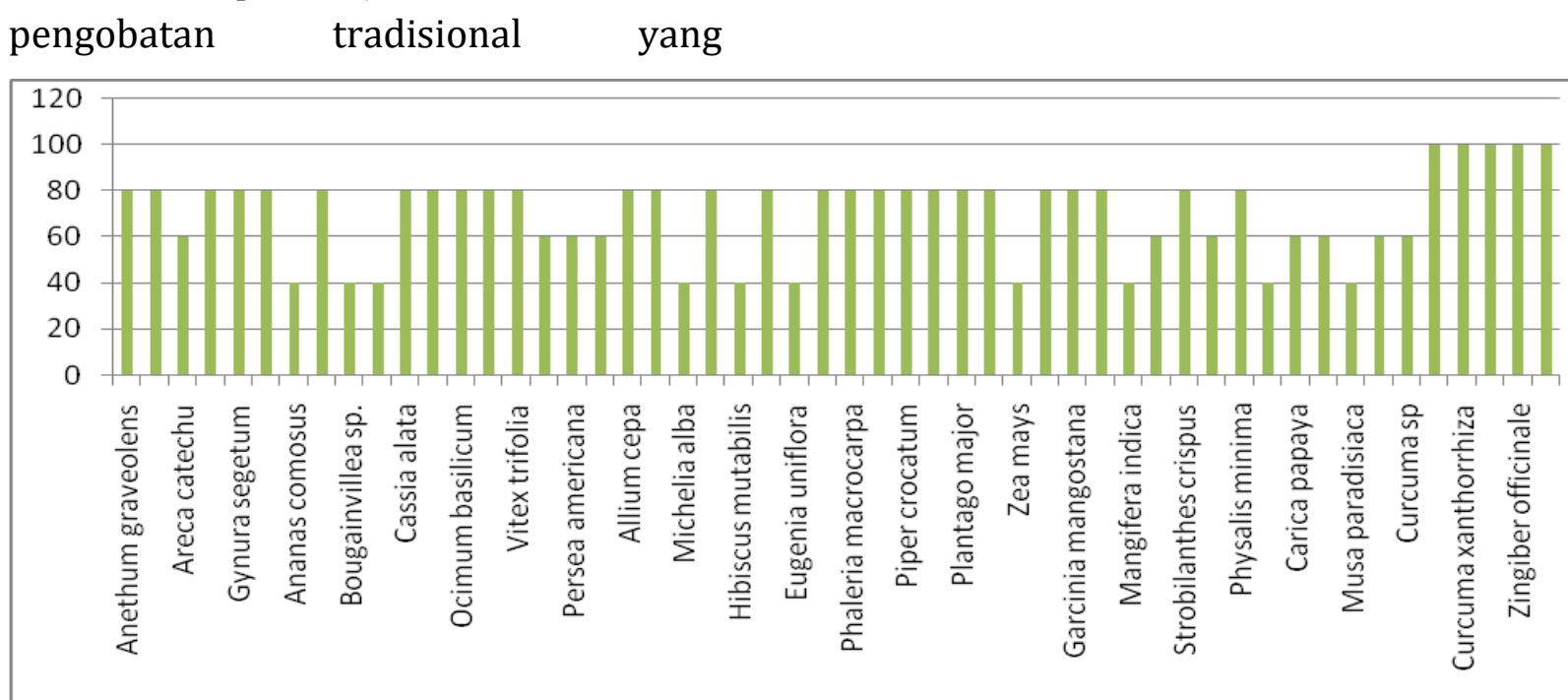

\section{Grafik 1. Persentase Jenis Tumbuhan Obat}

Dari Grafik 1. Diatas dapat dilihat bahwa persentase Jenis tumbuhan Obat yang paling banyak digunakan adalah Curcuma longa, Curcuma xanthorrhiza, Kaemferia galanga, Zingiber officinale, dan Zingiber zerumbet dengan nilai $100 \%$. Jenis tumbuhan tersebut tergolong kelompok Suku Zingiberaceae. Tumbuhan ini banyak dimanfaat sebagai pengobatan penyakit seperti penetral racun, obat lambung, asam urat, lever, pegal linu dan keputihan.

Menurut Septiatin

(2008)

kandungan kimia dari suku Zingiberaceae umumnya mengandung minyak atsiri, pati, tannin, dan damar.
Kandungan dari minyak atsiri dapat mentabilkan sistem syaraf, menimbulkan perasaan senang, dan dapat menyembuhkan penyakit. Minyak atsiri bermanfaat bagi kesehatan karena kandungan senyawanya berfungsi melancarkan peredaran darah, sebagai penenang (sedatif), antiseptik, antipiretik (penurunan panas), karminatif, memperbaiki pencernaan dan sebagainya. Selain itu, senyawa metabolit sekunder yang dihasilkan tumbuhan dari suku Zingiberaceae umumnya dapat menghambat pertumbuhan mikroorganisme patogen yang merugikan. Jenis tumbuhan obat 
Situmorang, T.S. dan Sihombing, E.S.R, Kajian Pemanfaatan Tumbuhan Obat Pada Masyarakat

yang termasuk Zingiberaceae adalah Zingiber officinale, Kaemferia galanga, Curcuma longa dan Zingiber zerumbet. Bagian organ tumbuhan yang dimanfaatkan adalah rimpang. Sebab rimpang memiliki kandungan kimia dan efek farmakologis yang berpengaruh terhadap pengobatan penyakit.

Curcuma longa banyak digunakan sebagai memperlancar ASI, obat luka, sakit perut, meningkatkan nafsu makan serta memperlancar persalinan (Ashari, 1995). Curcuma longa mengandung kurkumin yang memberi zat warna kuning juga merupakan anti bakteri (Winarto, 2004). Tumbuhan ini juga berkhasiat sebagai obat penurun panas, diabetes melitus, tifus, usus buntu, haid tidak lancar, keputihan, nyeri haid, amandel, sesak nafas, dan cacar air.

Zingiber zerumbet mengandung senyawa kimia seperti minyak atsiri. Efek farmakologisnya diantaranya antiradang (anti-inflamasi) dan penambah nafsu makan. Rimpangnya berkhasiat untuk mengobati kejang pada anak, sakit perut, diare, disentri, gangguan empedu, kencing batu, radang ginjal, radang usus, radang lambung, menyegarkan badan, anemia, rematik, borok, penyakit kulit dan bisul (Hariana, 2005).

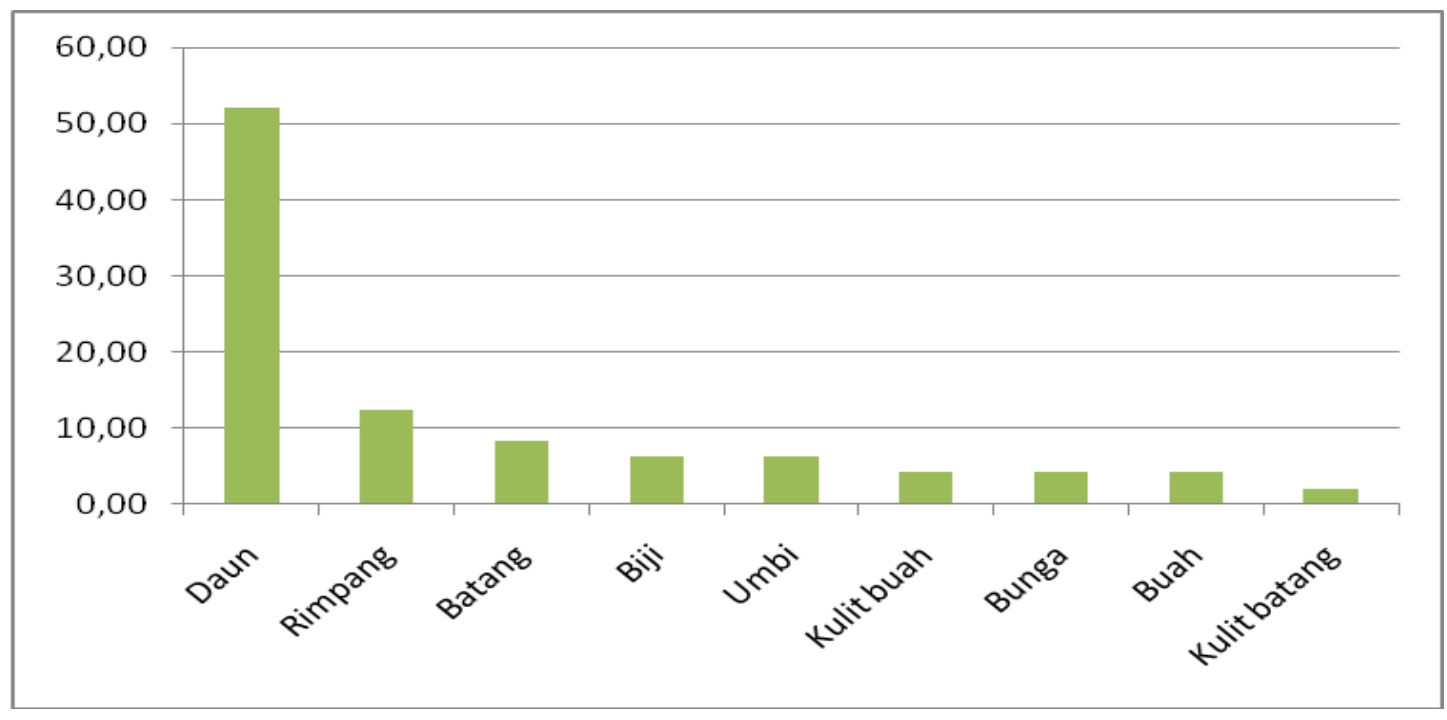

Grafik 2. Persentase Organ Tumbuhan Berkhasiat Obat

Dari Grafik 2. Dapat dilihat bahwa bagian organ tanaman yang sering dimanfaatkan sebagai obat tradisional adalah bagian daun dengan persentase $52,08 \%$. Daun paling tinggi intensitas penggunaannya karena mudah diperoleh daripada bagian organ tumbuhan lainnya. Daun merupakan organ tumbuhan yang pertumbuhannya terus menerus sehingga selalu tersedia pada tumbuhan. Dilihat dari segi konservasi, pengambilan daun sebagai tumbuhan obat tidak mengganggu dalam pelestarian tumbuhan obat tersebut.

Bagian organ tumbuhan yang banyak digunakan adalah rimpang $12,50 \%$. Biasanya dari golongan famili Zingiberaceae diantaranya Lengkuas, Kunyit, Temulawak, Kencur, Jahe dan Lempuyang. Penggunaan rimpang oleh Suku simalungun telah banyak 
digunakan. Salah satunya adalah Jahe (Zingiber officinale) yang mengandung zat zingiberin yang mampu berperan sebagai antimikroba.

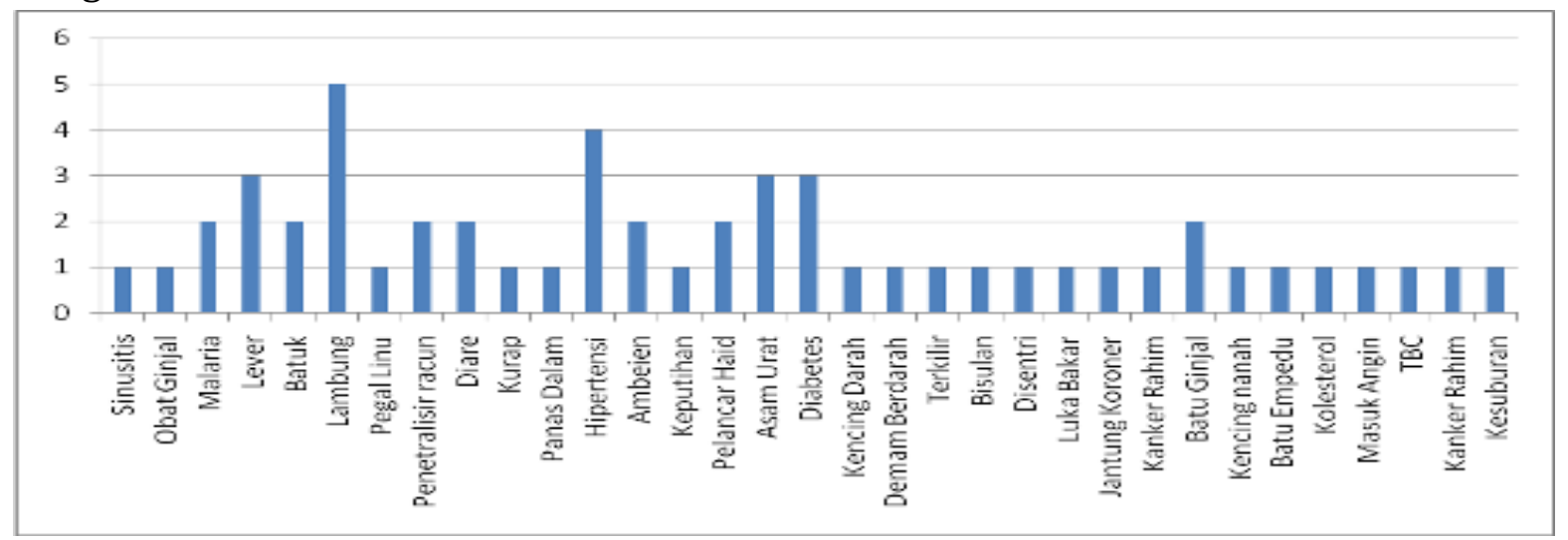

\section{Grafik 3. Data Ramuan Obat}

Dari grafik 3 diatas dapat dilihat bahwa ramuan pengobatan yang sering digunakan adalah ramuan obat lambung. Dalam pembuatan ramuan obat lambung, terdiri dari 5 ramuan dengan jenis-jenis tumbuhan obat yang digunakan relatif mudah di dapat seperti Curcuma longa, Curcuma sp., Tamarindus indica, Citrus aurantifolia, Michelia alba, Tinospora cordifolia, Cucurbita moschata, Eugenia uniflora dan beberapa yang bukan TO seperti Gula putih, gula merah, air, dan kuning telur.

\section{KESIMPULAN}

Adapun kesimpulan yang diperoleh adalah sebagai berikut: Diperoleh 53 Jenis Tumbuhan Obat yang terdiri dari 25 Ordo dan 33 Famili dari informasi 2 battra. Diperoleh 43 jenis ramuan dari 34 jenis penyakit. Famili Zingiberaceae merupakan famili yang paling banyak digunakan sebagai obat tradisional yaitu 12,96\%. Bagian organ tumbuhan yang digunakan sebagai bahan obat tradisional adalah bagian daun dengan persentase 52,08\%. Sumber Tumbuhan obat paling adalah hasil budidaya dengan nilai 75,46\%. Ramuan Obat yang paling banyak digunakan adalah Ramuan Obat lambung, Hipertensi, Diabetes, Asam Urat dan Lever.

\section{DAFTAR PUSTAKA}

Auliani. A., Fitmawati dan N. Sofiyanti. 2014. Studi Etnobotani Famili Zingiberaceae Dalam Kehidupan Masyarakat Lokal Di Kecamatan Siak Hulu Kabupaten Kampar. JOM FMIPA Volume 1 No.2

Bodeker, G. 2000. Indeneous Medical Knowledge: The law and Politics of Protection: Oxford Intellectual Property Research Centre Seminar in St.Peter's College, 25th January 200, Oxford

Dehlin, W. And Larsen K. 200o. Zingiberaceae. Flora of China.

Dharma, A. 2001. Uji Bioaktifitas Metabolit Sekunder. Makalah Workshop Peningkatan Sumber Daya Alam Hayati dan Rekayasa Bioteknologi. FMIPA UNAND, Padang

Handayani. 2003. Membedah Rahasia Ramuan Madura. Jakarta: Agromedia Pustaka.

Hariana A. 2008. Tumbuhan Obat dan Khasiatnta Seri 2. Penebar Swadaya. Depok 
Situmorang, T.S. dan Sihombing, E.S.R, Kajian Pemanfaatan Tumbuhan Obat Pada Masyarakat

Martin, G, J. 2004. Etnobotany: A People and Plant Concentration Manual. Chapmanand Hall. London

Kuntorini, E.M. 2005. Botani Ekonomi Suku Zingiberaceae Sebagai Obat Tradisional Oleh Masyarakat di Kotamadya Banjarbaru. BIOSCIENTIAE. Volume 2, Nomor 1, Januari.

Rifai, M.A. 1998. Pemasakinian Etnobotani Indonesia: Suatu Keharusan Demi Peningkatan Upaya Pemanfaatan, Pengembangan dan Penguasaannya. Prosiding Seminar Nasional Etnobotani III 5-6 Mei 1998, Denpasar-Bali): 352-356

Santoso, HB. 2008. Ragam dan Khasiat Tanaman Obat. Agromedia Pustaka: Jakarta.

Santhyami, dan Endah Sulistyawati. 2008. Etnobotani Tumbuhan Obat Oleh Masyarakat Adat Kampung Dukuh, Garut, Jawa Barat. School of Life Science \& Technology, Bandung Institute of Technology, Indonesia.

Septiantin, 20o8. Seri Tanaman Obat: Apotik Hidup dari Rempah-rempah, Tanaman Hias dan Tanaman Liar. Yrama Widya. Bandung

Siagian, M.H. \& Sunaryo. 1996. Pemanfaatan Suku Zingiberaceae Sebagai Obat Tradisional Oleh Masyarakat Lembak Delapan, Bengkulu. Abstr.0554. Hlm 246 Dalam Indeks Beranotasi Keanekragaman Hayati dalam Publikasi Ilmiah Staf Peneliti Pusat Penelitian Biologi-LIPI

Soekarman. 1991. Status Pengetahuan Etnobotani di Indonesia. Prosiding Seminar dan Lokakarya Nasional Etnobotani. Kerjasama Departemen Pendidikan dan Kebudayaan RI. Departemen Pertanian LIPI dan Perpustakaan Nasional RI, Bogor.

Supriati, R. Dan Kasrina. 2003. Studi Etnobotani Tapak Dara (Catharanthus) dan Kerabatkerabatnya Sebagai Tumbuhan Obat Pada Berbagai Golongan Etnis Di Kota Bengkulu. Makalah Seminar Nasional
PPD 2002 Forum HEDS (3-4 September 2003. Medan)

Swanson, T.M. 1995. Intellectual Property Rights and Biodiversity Conservation An Interdisciplinary Analysis of the Values if Medicinal Plants. Cambridge. University Press, Cambridge.

Yulianingsih, Dewi. 2002. Etnobotani pada Masyarakat Adat Kampung Naga, Desa Neglasari, Kecamatan Saluwu, Kabupaten Tasikmalaya, Propinsi Jawa Barat. Skripsi pada Jurusan Manajemen Hutan, Fakultas Kehutanan. IPB, Bogor. Tidak Diterbitkan.

Winarto, W.P. 2004. Khasiat dan manfaat Kunyit. Agromedia Pustaka. Jakarta.

Simanjuntak, H.A., (2016), Etnobotani Tumbuhan Obat di Masyarakat Etnis Simalungun Kabupaten Simalungun Provinsi Sumatera Utara, BioLink, Vol. 3 (1), Hal: 75-8o.

Simanjutak, H.A., 2017. Potensi Famili Asteraceae Sebagai Obat Tradisional Di Masyarakat Etnis Simalungun Kabupaten Simalungun Provinsi Sumatera Utara, BioLink, Vol. 4 (1) Hal. 11-18. 
BioLink, Vol. 4 (2) Januari 2018: hal. 112-120 